\title{
EFEKTIVITAS MEDIA AUDIO VISUAL TERHADAP KECERDASAN VISUAL SPASIAL ANAK USIA 5-6 TAHUN
}

\author{
Mein Fitri Fathonah', Siti Wahyuningsih', Muhammad Munif Syamsuddin ${ }^{1}$ \\ 1Program Studi PG-PAUD, Universitas Sebelas Maret \\ Email: fitrifathonahmein@gmail.com,siti_w@ staff.uns.ac.id,wandamunif@yahoo.com
}

\begin{abstract}
ABSTRAKPenelitian ini bertujuan untuk menguji efektivitas media audio visual terhadap kecerdasan visual spasial pada anak usia 5-6 tahun. Penelitian ini merupakan penelitian kuantitatif quasi eksperimen dengan desain non equivalent control group design. Sampel penelitian ini sejumlah 41 anak usia 5-6 tahun di TK Aisyiyah 1 Nusukan dan TK Aisyiyah 3 Nusukan, Surakarta. Validitas instrumen menggunakan validitas isi. Teknik pengumpulan data melalui tes untuk mengukur kecerdasan visual spasial anak. Uji normalitas dan uji homogenitas menggunakan kolmogrovsmirnov dan lavene test of equality of variance. Analisis data penelitian menggunakan statistik parametrik setelah data dinyatakan normal dan homogen dengan taraf signifikansi $p \geq 0,05$. Uji hipotesis menggunakan t-test dengan SPSS 15 for windows. Hasil analisis data menunjukkan bahwa pertama, hasil kedua kelompok menunjukkan adanya peningkatan, rata-rata pretest kelompok eksperimen sebesar 27,13 meningkat menjadi 34,81 pada saat posttest, sedangkan rata-rata pretest kelompok kontrol sebesar 25,36 meningkat menjadi 30,57 pada saat posttest. Kedua, terdapat efektivitas media audio visual terhadap kecerdasan visual spasial anak usia 5-6

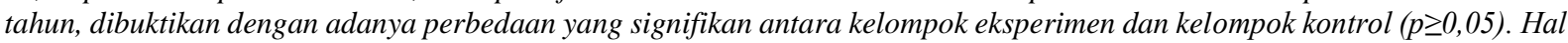
ini membuktikan bahwa hampir seluruh anak pada kelompok eksperimen telah mampu dalam mengelompokkan benda berdasarkan warna, bentuk, dan ukuran, mengurutkan benda berdasarkan ukuran dari paling kecil ke paling besar atau sebaliknya, menggambar suatu macam benda atau objek yang telah dilihat, dan menggambar berbagai bentuk yang berbedabeda. Berdasarkan uraian di atas dapat disimpulkan bahwa media audio visual memberikan efektivitas terhadap kecerdasan visual spasial pada anak kelompok B TK Aisyiyah 1 Nusukan Surakarta.
\end{abstract}

Kata kunci: media audio visual, kecerdasan visual spasial, anak usia dini.

ABSTRACKThis study aimed to test the effectiveness of audio-visual media on visual-spatial intelligence in children aged 5 6 years. The research was quantitative quasi eksperiment non-equivalent design. The sample of this study was 41 childrens aged 5-6 years in Aisyiyah 1 Nusukan Kindergarten and Aisyiyah 3 Nusukan Kindergarten, Surakarta. Instrument validity used content validity. Data collection techniques werethrough tests to measure the child's visual-spatial intelligence. Normality test and homogeneity test used kolmogrovsmirnov and lavene test of equality of variance. Analysis of research data used parametric statistics, after the data are declared normal and homogeneous with a significance level $p \geq 0.05$. Hypothesis testing used $t$-test through SPSS 15 for windows. The results of data analysis showed that first, the results of both groups showed an increase, the average pretest of the experimental group of 27.13 increased to 34.81 at the time of post-test, while the average pretest of the control group of 25.36 increased to 30.57 at the time of post-test. Second, there is effectiveness of audio-visual media on visual-spatial intelligence of children aged 5-6 years, evidenced by the significant differences betwen the experimental grup and the control grup ( $p \geq 0.05)$. This proves that almost all children in the experimental grup have been able to grup objects by color, shape, and size, sort objects by size from smallest to largest or otherwise, draw a variety of objects or objects that have been seen, and draw a variety of different shapes.Based on the description above can be concluded that audio-visual media provide effectiveness on visual-spatial intelligence in grup B children aged 5-6 years at TK Aisyiyah Nusukan 1 Surakarta.

Keywords:audio-visual media, visual-spatial intelligence, early childhood. 


\section{PENDAHULUAN}

Kecerdasan merupakan kemampuan tertinggi yang dimiliki oleh manusia. Pengembangan kecerdasan akan lebih baik jika dilakukan sedini mungkin sejak anak dilahirkan melalui pemberian stimulasi pada kelima panca indranya (Sujiono \& Sujiono, 2010). Gardner (Karamikabir, 2012) mengatakan bahwa setiap anak memiliki potensi kecerdasan yang berbeda-beda. Kecerdasan tidak hanya tunggal, tetapi terdiri dari beberapa kecerdasan atau kecerdasan jamak (multiple inteligences). Salah satu kecerdasan yang dimiliki anak yaitu kecerdasan visual spaial.

Pada proses pembelajaran anak seringkali dihadapkan pada aktivitas yang membutuhkan pemecahan masalah. Pemecahan masalah dapat dilakukan anak dengan adanya kecerdasan visual sapasial. Hal ini sesuai dengan pernyataan Papalia, Old, dan Feldam (2008) bahwa kecerdasan visual spasial digunakan oleh anak untuk berpikir dalam bentuk visualisasi dan gambar untuk memecahkan sesuatu masalah atau menemukan jawaban. Selain dapat memecahkan masalah, kecerdasan visual spasial sangat dibutuhkan anak untuk belajar secara visual, menyusun segala sesuatu melalui penglihatan, dan menyukai gambar, maupun apapun yang tertangkap oleh mata (Morrison, 2012).

Kecerdasan visual spasial pada perkembangan anak usia dini disesuaikan dengan kurikulum dua aspek perkembangan, yaitu kognitif dan seni. Sesuai yang dinyatakan dengan Sujiono dan Sujiono (2010), bahwa perkembangan kognitif dan seni mencakup kemampuan kecerdasan visual spasial. Perkembangan kognitif mencakup seperti mengetahui bentuk dan ruang. Perkembangan seni mencakup didalamnya seperi menggambar. Standar kecerdasan visual spasial anak usia dini meliputi kepekaan terhadap warna, garis, bentuk dan ruang, mencakup kemampauan untuk memvisualisasikannya (Amstrong, 2013).

Berdasarkan teori yang telah dijelaskan oleh para ahli mengenai kecerdasan visual spasial, penulis mengadaptasi teori kecerdasan visual spasial dengan Standar Tingkat Perkembangan Anak dalam Permendikbud No 137 Tahun 2014 untuk menentukan perkembangan anak usia 5-6 tahun. Aspek perkembangan kognitif yang temasuk dalam kecerdasan 
visual spasial yaitu:

mengklasifikasikan benda berdasarkan warna, bentuk, dan ukuran, mengurutkan benda berdasarkan ukuran dari paling kecil ke paling besar atau sebaliknya, dan (3) menggambar suatu benda atau objek yang telah dilihat. Aspek perkembangan seni yang termasuk dalam kecerdasan visual spasial yaitu menggambar berbagai macam bentuk yang berbeda.

Hasil observasi dilapangan yaitu ditemukan hambatan pada saat anak diminta untuk mengumpulkan kertas berwarna sesuai dengan warna, bentuk, dan ukuran. Anak mengerti perbedaan masing-masing, namun masih kesulitan dan membutuhkan bantuan. Anak-anak masih sulit menggambarkan benda atau objek yang telah dilihatnya dan menggabar beberapa bentuk geometri. Ketika dalam suatu kegiatan pembelajaran, tugas yang diberikan oleh guru adalah mengambar ular, hanya sebagian kecil anak yang mampu menggambarkannya, sedangkan yang lainnya tidak menyerupai. Pada saat guru memerintahkan anak menggambar bentuk segitiga, juga terdapat beberapa anak yang masih kesulitan. Hal ini dikarenakan kurangnya variasi penyampaian pembelajaran, sehingga berdampak pada kurangnya kemampuan visual spasial anak. Akibatnya anak kurang memiliki kemampuan kecerdasan visual spasial dan kegiatan kurang menarik minat anak.

Media pembelajaran merupakan pembawa informasi dari guru kepada sisiwa, dan salah satu cara guru untuk membuat kegiatan pembelajaran menjadi menarik dan menyenangkan (Khairani, 2017). SelanjutnyaMursid (2017) menyatakanbahwa media dalam proses pembelajaran dapat mempertinggi proses belajar siswa dalam pembelajaran yang pada gilirannya diharapkan dapat mempertinggi hasil belajar yang dicapainya. Proses dan hasil belajar pada siswa menunjukkan perbedaan yang signifikan antara pembelajaran tanpa media dan pembelajaran menggunakan media (Makokha, 2013). Oleh karena itu, penggunaan media pembelajaran sangat dianjurkan untuk mempertinggi kualitas pembelajaran. Pembelajaran yang menyenangkan merupakan pembelajaran yang dapat memberikan pengalaman dan pengetahuan yang nantinya akan selalu diingat. Pembelajaran tersebut seperti melihat dan mendengar dengan bersamaan dengan tampilan yang menarik. Salah 
satu media pembelajaran yang melibatkan penglihatan dan pendengaran yaitu media audio visual (Mallekian \& Khazaee, 2012).

Media audio visual merupakan bahan ajar yang mengkombinasikan visual dan audif digunakan untuk merangsang indera penglihatan dan indera pendengaran anak. Sanaky (2015) mengungkapkan bahwa media audio visual merupakan media yang dapat menampilkan unsur gambar (visual) dan suara (audio) secara bersamaan pada saat mengkomunikasikan pesan atau informasi. Media pembelajaran tersebut memberikan kesempatan kepada anak untuk menangkap, menyimpan, dan menampilkan kembali objek yang telah dilihatnya kedalam gambar, garis, maupun mewarnai. Menurut Munandi (Arsyad, 2015) salah satu bentuk media audio visual adalah video.

Ode (2014) meneliti tentang penggunaan media dalam pembelajaran. Penelitian tersebut menjelaskan bahwa dampak penggunaan sumber daya audio visual pada pengajaran dan pembelajaran terletak pada kenyataan bahwa mereka merangsang minat dan meningkatkan pembelajaran. Pembelajaran menggunakan media audio visual menurut Anitah (2009) memiliki beberapa tahap pelaksanaan kegiatan pembelajaran, dimulai dari persiapan hingga tindak lanjut. Pada tahap tindak lanjut, anak diminta untuk memvisualisasikan apa yang telah dilihat maupun didengarnya dalam bentuk gambar, garis, maupun mewarnai. Proses memvisualisasikan ini merupakan perkembangan kecerdasan visual spasial anak usia 5-6 tahun. Berdasarkan pemasalahan di atas, peneliti melakukan penelitian dengan judul "Efektivitas Media Audio Visual terhadap Kecerdasan Visual Spasial Anak Usia 56 Tahun".

\section{Kecerdasan Visual Spasial Anak Usia Dini}

Kecerasan visual sapasial mencakup kesukaan pada gambar maupun video. Karamikabir (2012) berpendapat bahwa kecerdasan visual spasial berarti kemampuan untuk berfikir dalam bentuk gambar, ruang, bentuk grafis, dan hubungan-hubungan yang ada diantara unsur-unsur tersebut. Kecerdasan memungkinkan seseorang menangkap apa yang telah dilihatnya. Seperti yang dikatakan Mursid (2017 bahwa kecerdasan visual spasial merupakan kemampuan untuk belajar secara visual, menyusun segala sesuatu melalui penglihatan, dan menyukai 
gambar, maupun apapun yang tertangkap oleh mata.

Kecerdasan visual spasial anak usia 4-6 tahun berkembang seiring dengan kemampuan anak untuk mengintegrasikan visual, seperti kemampuan untuk mentransfer keduanya dalam bentuk garis, bentuk, warna, lembar, ukuran, dan hubungan di antara aspek tersebut (Jamaris \& Edwita, 2014). Selanjutnya Yus (2012) menyatakan bahwa kemampuan visual spasial anak 5-6 tahun yaitu: anak dapat membuat gambar dengan pesan tertentu, memperoleh informasi melalui seni, menggunakan berbagai peralatan seni untuk membuat sesuatu, dan menggambar objek sesuai dengan imajinasi.

Perkembangan kecerdasan visual spasial anak usia 4-6 tahun berkembang sejalan dengan kemampuan anak. Kemampuan anak dalam kecerdasan visual spasial seperti anak mampu memahami visual, dan anak mampu mengaplikasikan dalam bentuk garis, warna, gambar, bentuk, maupun ukuran. Indikator Kecerdasan visual spasial anak usia 4-6 tahun yaitu: anak mampu mengklasifikasikan benda berdasarkan warna, bentuk, dan ukuran (3 variasi), mengurutkan benda berdasarkan uuran

dari paling kecil ke paling besar atau sebaliknya, menggambar suatu benda atau objek yang telah dilihat, dan menggambar berbagai macam bentuk yang beragam.

\section{Media Audio Visual}

Media audio visual adalah media pengajarandan media pendidikan yang mengaktifkan mata dan telinga peserta didik dalam waktu proses belajar mengajar berlangsung (Djamarah \& Zain, 2002). Sanjaya (2011) menyatakan bahwa media audio visual yaitu jenis media yang selain mengandung unsure suara juga mengandung unsure gambar yang dapat dilihat, seperti rekaman video, berbagai ukuran film, slide suara, dan lain sebagainya. Kemampuan media inidianggap lebih baik dan lebih menarik, sebab mengandung kedua unsure jenis media yang pertama dan kedua.

Khulluqo (2017) menjelaskan bahwa media audio visual merupakan bahan ajar yang menggabungkan dua materi, yaitu: material visual danauditif. Contohnya, kaset, video, atau CD video dan termasuk siaran TV. Arsyad (2015) mengungkapkanb ahwa media audio visual merupakan penggunaan materi yang penyerapannya melalu ipandangan dan pendengaran dengan cara 
menampaikan menggunakan mesinmesin mekanis dan elektronik untuk menyajikan pesan-pesan audio dan visual.

Berdasarkan pendapat dari beberapa ahli, maka dapat disimpulkan media video visual adalah media yang merupakan kombinasi antara media audio dan media visual, yang melibatkan indera pendengaran dan penglihatan untuk menangkap informasi, dengan cara menampilkan menggunakan mesinmesin mekanis dan elektronik.

Pada penelitian ini, video menjadi media audio visual yang digunakan untuk dijadikan sebagai tindakan untuk masalah yang terjadi. Khususnya video animasi gambar bergerak yang dapat menarik minat anak. Pemilihan video juga dapat disesuaikan dengan tema yang ada, guru dapat menentukan beberapa video sekaligus dalam satu tema. Video yang digunakan diambil dari beberapa sumber dari youtube yang disesuaikan dengan tema yang ada.

Penggunaan media video dalam pembelajaran terdiri dari beberapa tahap, dimulai dengan persiapan, dilanjutkan tahap pelaksanaan dengan menayangkan video sesuai tema, dan anak menonton, memperhatikan. Setelah selesai anak menonton video, anak mengerjakan tugas dari guru, ini masuk pada tahap evaluasi. Pada tahap akhir yaitu tahap tindak lanjut anak diperintahkan untuk menggambar bentuk atau objek yang telah dilihatnya.

\section{METODE PENELITIAN}

Penelitian yang dilaksanakan termasuk dalam penelitian quasi eksperimental design dengan tipe non equivalent control group design. Penelitian ini dilaksanakan di TK Aisyiyah Nusukan 1 dan Aisyiyah Nusukan 3 Surakarta anak kelompok B. Penelitian dilakukan dengan jangka waktu dua belas bulan dimulai dari bulan Januari sampai dengan Desember 2019. Populasi dalam penelitian ini yaitu satu gugus yang terdiri dari delapan TK yang selanjutnya diambil dua TK secara acak. Selanjutnya, semua responden sejumlah 41 anak terdiri dari sampel 22 anak sebagai kelompok eksperimen dan 19 anak menjadi sampel kelompok kontrol.

Tenik pengumpulan data dilakukan melalui tes dan dokumentasi, tes untuk mengetahui kecerdasan visual spasial anak, tes yang dilakukan berupa pretest dan posttest. Soal tes berupa lembar kerja anak yang diberikan pada saat pre test dan posttest. Penilaian terhadap hasil tes, menggunakan rating 
scale yang memiliki nilai skala 1-4. Sedangkan dokumentasi digunakan untuk memberikan informasi tambahan mengenai kecerdasan visual sapsial anak selama penelitian dilakukan.

Uji validitas yang digunakan yaitu validitas isi, dalam menguji validitas isi dengan mengacu pada instrumen kecerdasan visual spasial yang diadaptasi dari STPPA (Standar Tingkat Pencapaian Perkembangan Anak) dalam Peraturan Menteri Pendidikan dan Kebudayaan Republik Indonesia Nomor 137 Tahun 2014 yang kemudian dikonsultasikan kepada ahli (expert judgment). Uji reliabilitas dalam penelitian ini menggunakan Cronbach'sAlpha dengan bantuan SPSS 15 for windows dengan nilai mencapai 0,209 .

Teknik analisis data menggunakan statistik parametrik, uji prasyarat analisis melalui uji normalitas dengan menggunakan shapiro wilk, sedangkan uji homogenitas dilakukan dengan menggunakan laevene test of equality of variance. Uji hipotesis menggunakan independent sample t-tes dengan bantuan SPSS 15 for windows digunakan untuk membandingkan ratarata nilai kelompok eksperimen dan kelompok kontrol.

\section{HASIL DAN PEMBAHASAN}

Penelitian ini menggunakan uji prasayarat yang terdiri dari uji normalitas dan uji homogenitas. Kedua uji prasyarat tersebut dilakukan dengan tujuan untuk mengetahui data yang diperoleh terdistribusi normal dan homogen, sehingga dapat dikategorikan kedalam penelitian statistik parametrik. Uji normalitas dalam penelitian ini menggunakan teknik analisis shapirowilk, dan data dinyatakan normal jika nilai signifikansi $p \geq 0,05$.

Tabel 1..Uji Normalitas

\begin{tabular}{ccccc}
\hline \multirow{2}{*}{ Test } & \multirow{2}{*}{ Kelompok } & \multicolumn{3}{c}{ Shapiro-wilks } \\
\cline { 3 - 6 } & & Statistic & $d f$ & Sig. \\
\hline \multirow{2}{*}{ Pretest } & Eksperimen &, 167 & 22 &, 122 \\
& Kontrol &, 145 & 19 &, 878 \\
\multirow{2}{*}{ Posttest } & Eksperimen &, 191 & 22 &, 082 \\
& Kontrol &, 140 & 19 &, 421 \\
\hline \multicolumn{2}{c}{ Hasil } & uji & \multicolumn{3}{c}{ normalitas }
\end{tabular}

menunjukkan tingkat signifikansi kelompok eksperimen pada saat pretest 0,122 , dan nilai signifikansi posttest yaitu 0,878 . Berdasarkan hasil pengujian yang dilakukan menunjukkan data berdistribusi normal yang artinya kecerdasan visual spasial anak heterogen dari tinggi, sedang, hingga belum berkembang optimal.

Teknik analisis homogenitas dalam penelitian ini menggunakan 
levene test for equalityof variance, dengan dasar pengambilan keputusan data homogen jika nilai signifikansi $p \geq$ 0,05 .

Tabel3. Uji Homogenitas

\begin{tabular}{lcc}
\hline & $P$ & $p$ HasilAnalisis \\
\hline Pretest & $p>0,05$ & 0,415 \\
Postest & & 0,156
\end{tabular}

\section{Berdasarkan uji homogenitas pada} data pretest maupun posttest menunjukkan nilai signifikansi $p \geq 0,05$, maka dapat disimpulkan bahwa kedua kelompok data kecerdasan visual spasial anak antara pretest maupun posttest memiliki varian yang sama (homogen).

Tabel 4. Uji independent sample t-test

\begin{tabular}{ccccc}
\hline Test & Kelompok & N & Mean & P \\
\hline \multirow{2}{*}{ Pretest } & Eksperimen & 22 & 27,13 & 0,100 \\
& Kontrol & 19 & 25,36 & \\
\multirow{2}{*}{ Postest } & Eksperimen & 22 & 34,81 & 0,005 \\
& Kontrol & 19 & 30,57 &
\end{tabular}

Berdasarkan tabel diatas dapat disimpulkan bahwa hasil sebelum perlakuan antara kelompok eksperimen dan kelompok kontrol tidak terdapat perbedaan yang signifikan, dengan taraf signifikansi $p \geq 0,05$. Setelah adanya perlakuan, hasil menunjukkan adanya perbedaan yang signifikas dengan taraf signifikansi $p \leq 0,05$. Perbedaan yang signifikan tersebut menunujukkan bahwa terdapat efektivitas media audio visual terhadap kecerdasan visual spasial anak usia 5-6 tahun. Hal tersebut juga dilihat dari rata-rata hasil tes setelah diberikan perlakuan memiliki perbedaan antara kelompok eksperimen dan kelompok kontrol. Hasilnya lebih tinggi kelompok ekperimen dan perubahan sesudah diberikan perlakuan mengalami peningkatan.

Berdasarkan analisis data penelitian dan pengujian hipotesis dapat disimpulkan bahwa, terdapat efektivitas media audio visual terhadap kecerdasan visual spasial anak usia 5-6 tahun. Diketahui dari rata-rata kelompok eksperimen dan kelompok kontrol. Pada kelompok kontrol diberi perlakuan dengan media gambar/foto menunjukkan bahwa hasil posttest mengalami sedikit peningkatan. Sedangkan pada kelompok eksperimen yang mendapatkan perlakuan berupa media audio visual menunjukkan hasil posttest mengalami peningkatan yang cukup signifikan, namun kedua kelompok tetap diberikan dengan indikator yang sama. Anak-anak pada kelompok eksperimen lebih mampu mengelompokkan benda berdasarkan warna, bentuk, dan ukuran. Anak juga lebih mampu mengurutkan benda berdasarkan ukuran dari paling kecil ke paling besar atau sebalikya. 
Setiap media memiliki nilai-nilai positif dan edukatif yang berguna bagi pengembangan semua aspek kecerdasan anak terutama kecerdasan visual spasial. Pada kelompok eksperimen anak-anak diberikan perlakuan berupa media audio visual dengan empat kegiatan. Keempat kegiatan tersebut terdapat pada Standar Tingkat Perkembangan Anak dalam Permendikbud No 137 Tahun 2014 yaitu: (1) mengelompokkan gambar benda berdasarkan bentuk, warna, dan ukuran, kemudian ditempel pada lembar kertas, (2) mengurutkan dari besar ke kecil maupun sebaliknya gambar kapal dan pohon kemudian menempel pada lembar kertas, (3) menggambar benda bergerak (kapal) dan benda diam (pohon) dengan fariasi pada lembar kertas, (4) menggambar berbagai bagian pada kapal yang berbentuk segitiga, lingkaran, dan persegi.

Kegiatan yang pertama yaitu, mengelompokkan gambar benda sesuai bentuk, warna dan ukuran yang telah disediakan. Anak diminta untuk mengelompokkan lalu menempelkan beberapa gambar benda yang berwarna kuning, seperti gambar kapal, kontainer, pintu kapal, dan turbin kapal. Dilanjut gambar benda yang berbentuk lingkaran, seperti gambar teropong, jendela kapal, pelampung, dan setir kapal. Kemudian gambar benda yang memiliki ukuran sama, yaitu gambar jendela kapal, pintu kapal, lemari, dan meja di kapal. Gambar-gambar yang ada disesuaikan dengan tema hari itu. Seperti yang dikatakan oleh Amstrong (2013) bahwa kecerdasan visual spasial melibatkan kepekaan terhadap warna, garis, bentuk dan ruang, mencakup kemampauan untuk memvisualisasikan. Ketika anak memilih dan menempel gambar benda berdasarkan warna, bentuk, dan ukuran yang sama, anak melatih kepekaan terhadap hal tersebut. Kegiatan tersebut memasukkan indikator mengelompokkan benda berdasarkan warna, bentuk, dan ukuran.

Kedua, mengurutkan gambar benda dari yang terkecil ke terbesar, maupun sebaliknya. Seperti yang dikatakan Mursid (2017) bahwa kecerdasan visual spasial merupakan kemampuan untuk belajar secara visual, menyusun segala sesuatu melalui penglihatan, dan menyukai gambar, maupun apapun yang tertangkap oleh mata. Terdapat beberapa gambar pohon kelapa dan kapal dengan berberapa ukuran yang telah disediakan. Anakanak diajak untuk mengurutkan kemudian menempel gambar acak yang 
terdiri dari beberapa ukuran gambar, baik dari terkecil ke terbesar maupun dari terbesar ke terkecil. Mengurutkan dilakukan dengan benda yang sejenis, seperti gambar kapal dari yang terbesar ke gambar kapal yang terkecil, maupun gambar pohon kelapa dari terkecil ke gambar pohon kelapa yang terbesar. Kegiatan ini memasukkan indikator mengurutkan benda berdasarkan ukuran dari paling kecil ke paling besar atau sebaliknya.

Ketiga, menggambar suatu objek atau benda bergerak dan diam. Anak menggambar benda atau objek sesuai tema pada hari itu, yaitu satu pohon kelapa dan satu buah kapal yang telah dilihatnya melalui tayangan video yang telah ditonton. Sejalan dengan Noorlaila (2010) bahwa kecerdasan visual spasial merupakan kemampuan dalam memvisualisasikan apa yang ada di benaknya lewat gambar. Anak dapat menambahkan gambar pendukung, atau gambar tambahan benda-benda yang ada disekitar benda yang digambar sesuai imajinasi anak, seperti awan, ikan, dan batu. Kegiatan ini memasukkan indikator menggambar suatu benda atau objek yang telah dilihatnya.

Keempat, menggambar berbagai bagian kapal yang berbentuk lingkaran, persegi, dan segitiga. Setelah anak memperhatikan dan menonton tayangan video tentang bentuk, anak ditugaskan untuk menggambar benda apa saja pada video yang telah dilihatnya. Ada yang berbentuk lingkaran, persegi, maupun segitiga. Anak menggambar beberapa benda setiap satu bentuk, seperti teropong, pelampung, dan setir kapal untuk bentuk lingkaran. Sedangkan untuk bentuk persegi seperti kaca kapal, dan layar kapal untuk bentuk segitiga. Sependapat dengan Jamaris dan Edwita (2014) kecerdasan spasial visual merupakan kemampuan yang berkaitan dengan kepekaan dalam mengintegrasikan persepsi visual dan pemikiran, serta, mentransfer persepsi visual dalam gambar. Anak dapat menggambar berbagai benda yang ada di video maupun disekitar anak. Anak berimajinasi dan mengembangkan apa yang telah dilihatnya, sehingga melatih kemampuan untuk memahami dan menciptakan kembali dalam berbagai bentuk. Kegiatan ini memasukkan indikator menggambar berbagai bentuk yang berbeda-beda.

Media audio visual efektif terhadap kecerdasan visual spasial anak usi 5-6 tahun. Anak mampu mengelompokkan gambar benda warna 
merah, gambar benda berbentuk lingkaran, dan gambar benda yang memiliki ukuran yang sama, mengurutkan gambar benda berdasarkan ukuran dari paling kecil ke paling besar, atau sebaliknya, menggambar suatu macam benda atau objek yang telah dilihat, dan menggambar berbagai bentuk yang berbeda-beda. Selain itu, media audio visual merangsang anak menangkap apa yang telah dilihatnya maupun yang didengar. Sejalan Djamarah dan Zain (2002) mengatakan bahwa media audio visual adalah media pengajaran dan media pendidikan yang mengaktifkan mata dan telinga peserta didik dalam waktu proses belajar mengajar berlangsung. Anak merespon apa yang telah dilihat maupun yang telah didengarnya, penglihatannya akan apa yang ditampilkan membuat anak menjadi lebih bebas untuk mengekspresikan imajinasinya.

Pembelajaran melalui media audio visual efektif untuk perkembangan kognitif anak dalam proses pembelajaran. Sependapat dengan Munandi (2013) bahwa pemakaian video untuk tujuan kognitif dapat digunakan untuk hal-hal yang menyangkut kemampuan mengenal kembali dan kemampuan memberikan rangsangan berupa gerak yang serasi. Seperti pengamatan terhadap kecepatan relatif suatu objek atau benda yang bergerak, penyimpangan, dalam gerak interaksi antara objek dan benda.Adapun dampak dari treatment kelompok kontrol dengan media gambar, sehingga tidak memberikan wawasan dan pengamatan yang lebih nyata dan menarik. Lembar kegiatan anak disesuaikan dengan indikatior yang sama dengan kelompok eksperimen.

\section{SIMPULAN}

Penelitian ini mengkaji tentang media audio visual berupa video yaitu kombinasi antara media audio dan media visual, yang melibatkan indera pendengaran dan penglihatan untuk menangkap informasi. Hasil penelitian menunjukkan bahwa terdapat efektifitas media audio visual terhadap kecerdasan visual spasial anak usia 5-6 tahun. Hal ini dibuktikan dengan adanya peningkatan nilai rata-rata pretest kelompok eksperimen setelah dilakukan posttest.

\section{DAFTAR PUSTAKA}

Amstrong, T. (2013). Kecerdasan multiple. Jakarta Barat: Indeks.

Anitah. (2009). Media pembelajaran. Surakarta: Mata Padi Persindo.

Arsyad, A. (2015). Media pembelajaran. Jakarta: Rajagrafindo Persada.

Beceran, B. O. (2010). Determining multiple intelligences preschoolchildren (4-6 Age) in 
learning process. Social and Behavioral Sciences, 2, 24732480.

Peraturan Menteri Pendidikan dan Kebudayaan Republik Indonesia Nomor 137 Tahun 2014 Standar Pendidikan Anak Usia Dini. Kementerian Pendidikan dan Kebudayaan Tahun 2015. Jakarta.

Djamarah, S. B., \& Zain, A. (2002). Strategi belajar mengajar. Jakarta: Rineka Cipta.

Jamaris, M., Edwita. (2014). Formal multiple intelligences assessment instruments for 4-6 years old children. American Journal of Educational Research, 2, 11611174.

Karamikabir, N. (2012). Gardner's multiple intelligence and mathematics education. Social and Behavioral Sciences, 31, 778-781.

Khairani, M. (2017). Psikologi belajar. Yogykarta: Aswaja Pessindo.

Khuluqo, I. E. (2017). Belajar dan pembelajaran. Yogyakarta: Pustaka Pelajar.

Makokha, W. C. (2013). Utilisation of educational media in teaching and learning of oral literature in buture sub country secondary schools, Kenya. International Journal of Science and Research, 5, 757-765.

Mallekian, F. \& Khazaee, R. (2012). Title: The relationship between emotional intelligence and the tendency rate to type of educational media in students. Sosial and Behavioral Sciences, 46, 3311-3315.

Morrison, G. S. (2012). Dasar-dasar pendidikan anak usia dini. Jakarta: Indeks.
Munandi, Y. (2013). Media pembelajaran. Jakarta: GP Press Group.

Mursid. (2017). Belajar dan pembelajaran PAUD. Bandung: PT Remaja Rosdakarya.

Noorlaila, I. (2010). Panduan lengkap PAUD. Yogyakarta: Pinus Book Publisher.

Ode, E. (2014). Impact of audio-visual (avs) resources on teaching and learning in some selected private secondary schools in Makurdi. International Journal of Research in Humanities, Art and Literature, 2, 195-202.

Papalia, D. F., Old, S. W., \& Feldam, R. D. (2008). Psikologi perkembangan. Jakarta: Kencana Media Group.

Sanaky, H. A. H. (2015). Media pembelajaran interaktif-inovatif. Yogyakarta: Kaukaba Dipantara.

Sanjaya, W. (2011). Perencanaan dan desain sistem pembelajaran. Jakarta: Kencana.

Sujiono, Y. N., \& Sujiono, B. (2010). Bermain kreatif berbasis kecerdasan jamak. Jakarta: Indeks.

Yus, A. (2011). Model pendidikan anak usia dini. Jakarta: Kencana 
KUMARA CENDEKIA Vol. 8 No. 2 Bulan Juni 2020 